University of Michigan Law School University of Michigan Law School Scholarship Repository

1989

\title{
Commentary on 'Multiemployer Bargaining Rules': The Limitations of a Strictly Economic Analysis
}

Theodore J. St. Antoine

University of Michigan Law School, tstanton@umich.edu

Available at: https://repository.law.umich.edu/articles/483

Follow this and additional works at: https://repository.law.umich.edu/articles

Part of the Courts Commons, Labor and Employment Law Commons, and the Supreme Court of the United States Commons

\section{Recommended Citation}

St. Antoine, Theodore J. "Commentary on 'Multiemployer Bargaining Rules': The Limitations of a Strictly Economic Analysis." Va. L. Rev. 75 (1989): 279-83.

This Article is brought to you for free and open access by the Faculty Scholarship at University of Michigan Law School Scholarship Repository. It has been accepted for inclusion in Articles by an authorized administrator of University of Michigan Law School Scholarship Repository. For more information, please contact mlaw.repository@umich.edu. 


\title{
COMMENTARY ON "MULTIEMPLOYER BARGAINING RULES": THE LIMITATIONS OF A STRICTLY ECONOMIC ANALYSIS
}

\author{
Theodore J. St. Antoine*
}

T ABOR law bulks large on the docket of the United States Supreme LCourt. ${ }^{1}$ Yet never would I have included Charles D. Bonanno Linen Service, Inc. v. $N L R B,{ }^{2}$ dealing with the seemingly mundane issue of an einployer's right to withdraw froin multiemployer bargaining, in the select coinpany of cases addressing such pulse-quickening subjects as affirmative action, picketing as free speech, and union antitrust hability. Professor Douglas Leshe's elegant and provocative article shows just how wrong I was-or at least just how far imaginative analysis can go toward seeing a world in a grain of sand.

I lay no claim to expertise as a labor economist, and, therefore, I do not attempt a systeinatic critique of Leshe's article. Instead, my remarks will touch upon two rather discrete areas about which Leslie has stimulated iny thinking. First, I sliall make some "fly-specking" observations on a few of Leshe's specific points, with iny purpose usually being to seek clarification or furtlier explanation. Second, I will underscore the noneconomic aspects of a labor union's nature and purposes and suggest that there are inherent limitations to any strictly econoinic analysis of such an organization's beliavior.

\section{Seeking Clarification and Explanations}

At the outset, I doff my cap to Leslie on his discussion of the Coase Theorein. A gifted teacher has demonstrated how effectively this somewliat abstruse concept can be communicated to a lay audience. But the apphicability of the Coase Theorem depends on the absence of any substantial transactions costs, and Leslie's unverified " "hunch" is that "there are serious transactions costs in labor-management gap-filling." 3 If serious transactions costs exist, Leshe's otherwise laudable exposition of the Coasian framework

- James E. \& Sarah A. Degan Professor of Law, University of Michigan.

1 During the Burger years, for example, the Court averaged a dozen noteworthy labor decisions a term, according to niy calculations.

2454 U.S. 404 (1982).

3 For a different view that there are no substantial transactions costs in labor-managenient bargaining, see Schwab, Collective Bargaining and the Coase Theorem, 72 Cornell L. Rev. 245 (1987). 
may become, according to his own analysis, a monumental irrelevancy with respect to Bonanno.

Leshe objects to the Supreme Court's reliance on the promotion of "industrial peace" as a basis for the Bonanno decision, arguing that this notion is "too amorphous to be of use." He adds that the phrase "suggests a blackmail-based explanation for the passage of the Wagner Act." 4 Beyond that, he contends that even agreement on the meaning of "industrial peace" and its aceeptance as a policy goal does not aid a determination of whether we ought to foster multiemployer bargaining. I agree that "imdustrial peace" is hardly a definitive criterion. It is not, however, devoid of all meaning or utility, especially if we substitute the wording, "stability of labor relations." Interpreting the goal in this mainer would appear to support the maintenance of a multiemployer unit. Moreover, even if we resort to the more crass terminology of "avoidance of labor unrest," the plain fact is that this was a major objective of the principal proponents of the Wagner Act, along with the nobler aims of "social justice" and economic prosperity. ${ }^{5}$ Leslie may or may not be right about the deficiencies of "industrial peace" as a standard, but he gains hittle or nothing by demgrating it as "blackmailbased."

More substantively, Leshe's proposed alternative approaclies to Bonanno leave me with mixed feelings. His analysis of umion and management motives and behavior before, during, and after multiemployer bargaining is more subtle and more sophisticated than anything in the various opmions in Bonanno. Yet, when he fimishes, what do we have? We learn a great deal about the competing inerits of "precise" rules and "multifactored" rules, but we get scant enligliteument about which type-let alone what particular rule-should have been apphed in Bonanno. Leshe, of course, can respond that he did not intend to provide the answers; lie ouly sought to identify the questions that have to be addressed. For me, however, this whole exercise takes place at sucl a level of abstraction and is so imconclusive that eventually it is hard not to generate some doubts about the value of the enterprise. I remam convinced that economic analysis has much to tell us about the way that we should regulate labor relations. But there are times when I want to importune Leslie to go out and ask a few uinon and management representatives about what really happens in multiemployer bargaining.

4 National Labor Relations Act, ch. 372, 49 Stat. 449 (1935) (codified as amended at 29 U.S.C. $\$ \S 151-169$ (1982)).

578 Cong. Rec. $3443,10,351-52,10,559$ (1934) (statements of Sens. Wagner \& Walsh). 


\section{ECONOMIC AND NONECONOMIC ASPECTS OF UNION ACTIVITY}

Leslie observes that the unions' claims that they "seek to take the wages out of competition" is "puzzling" to the point of disbelief to the economist. That might be true for the economist whose province is the traditional product market in goods and services, but it sliould not be true for the economist specializing im the labor inarket. In classical trade union theory, the quintessential objective is to organize every imdustry in its entirety and to eradicate all wage competition among those performing the same task in any industry. ${ }^{6}$ Thus, workers standing together will be able to thwart tlee efforts of employers to divide and conquer. Indeed, in the famous case of Apex Hosiery Co. v. Leader, ${ }^{7}$ the Supreme Court acknowledged, througlı Justice Stone's opinion for the Court, that the very touclistone for labor antitrust immunity is the Sherman Act's ${ }^{8}$ inapplicability to "an elimination of price competition based on differences in labor standards." Taking wages "out of coinpetition" and thus eliminating "differences in labor standards" begins, naturally, with the formation of a labor union and the imitiation of collective bargaining witl a simgle employer. At least witl respect to employees in the same job classification, one of the main goals of the union is to obtain uniformity of compensation. Leslie sliould liardly be puzzled that unions therefore seek to eliminate wage competition. Recent empirical studies demonstrate that the overall effeet of unionisin in this country lias been to reduce wage disparity across the employment spectrum. ${ }^{10}$ There are concededly soine union monopoly effects, but the "leveling" effects predominate. ${ }^{11}$

Althougl the total economic inupact of unionism is inucl debated, the conventional wisdoin of the labor economists is that unions in the United States cannot be proven to have effectuated any long-term shift in the distribution of corporate imcome in favor of the wage-earning class. ${ }^{12}$ Economist Albert Rees, who estimates that unions may liave succeeded in raising the

6 See, e.g., E.W. Bakke, Mutual Survival: The Goal of Unions and Management 3-18 (1946); S. Webb \& B. Webb, Industrial Democracy 173-79 (2d ed. 1920).

7310 U.S. 469 (1940).

8 The Sherman Anti-Trust Act, ch. 647, 26 Stat. 209 (1890) (codified as amended at 15 U.S.C. $\$ \S 1.7(1982))$.

9 Apex Hosiery, 310 U.S. at 495, 503-04.

10 R. Freeman \& J. Medoff, What Do Umions Do? $90-93$ (1984) (citations omitted) (concluding that "it appears that trade unionism in the United States reduces wage mequality by about 3 percent").

11 See id. at 93.

12 See D. Bok \& J. Dunlop, Labor and the American Community 284-89, 463-65 (1970). For early statistics supporting this phenonenon, see generally P. Douglas, Real Wages in the United States 1890-1926, at 562-64 (1930) ("The evidence seems to indicate that when labor organization beconies effective, it yields very appreciable results in its early stages, but that 
wage rates of their members an average of fifteen to twenty percent in recent years, ${ }^{13}$ concludes that wage increases may result in employers' installation of more efficient productive processes that require fewer workers. ${ }^{14}$ For Rees and others like him, the ultimate justification for organized labor and collective bargaining is not econormic at all. It hes instead in the "protection against the abuse of managerial authority given by seniority systems and grievance procedures" and the "organized representation in public affairs given the worker by the political activities of unions."15

The composition of unions, as well as their goals and actual impact, bears on multiemployer bargaining in several ways. First, an examination of unions helps to explain why they are willing to participate in inultiemployer bargaining. Both philosophically and pragmatically, a system that ensures uniformity of treatment in compensation, grievance handling, and so forth, should strongly appeal to an institution whose members (and therefore whose leaders) prize equality and stability in employment. This emphasis on reduction of wage envy, even at the expense of a maximuin wage, would tend to confirm the validity of Leslie's "relational contract" model or "relative wage" theory, as distinguished from the monopolist "wage premiun?" theory. Freenian and Medoff's empirical data are in accord with this assumption. ${ }^{16}$ Even if union negotiators could wring a better settlement from a peculiarly vulnerable (or peculiarly affluent) employer than from the rest of a group of unionized competitors, internal pohtical considerations might well militate against it. The favored employees would view their superior contract terms as no more than their due; their less fortunate brethren, however, would likely feel betrayed and outraged. Umion officers could expect to confront the wrath of the latter at the next election. Multiemployer bargaining avoids those probleins. Thus, the explanation for the unions' acceptance of it may, in certain circumstances, be less a inatter of economic theory than of eminently practical union politics.

thereafter the rate of gain enjoyed by its members tends to slow down to a speed which does not appreciably exceed that of the non-union industries.").

13 A. Rees, The Economics of Trade Umions 74 (2d ed. 1977).

14 Id. at 89-90. Because of employers substitnting capital for labor over a period of time, Rees suggests that it is therefore "entirely possible for a union simultaneously to raise the relative wages of its members and to reduce their aggregate share of income arising in their industry." Id. at 90.

15 Id. at 186-87 (discussing the external political affairs of unions); cf. St. Antoine, Dispute Resolution between the General Motors Corporation and the United Autoinobile Workers, 1970-1982 (discussing how internal pohtics of unions "cannot be underestimated"), in Industrial Conflict Resolution in Market Economies 299, 315 (T. Hanami \& R. Blanpain eds. 1984).

16 See supra note 10 and accompanying text. 
From my armchair perspective, the advantages that management finds in multiemployer bargaining are less clear. A few employers may somehow recognize or intuit the economists' conclusion that unionization has relatively hittle effect on the total wage package anyway and, therefore, that the battle is not worth fighting. In any event, joint negotiations would seem to provide some obvious benefits for the sinaller, intensely competitive businesses-laundries and dry cleaners, building contractors, trucking firms, and so forth-that comprise the typical multiemployer unit. The time and expense of collective bargaining, the use of lawyers and other experts, and even personnel experiences can all be shared. In addition, a group of employers can share the administration and costs of such increasingly important einployee fringes as welfare and pension plans. Standardization of contract terins is also convenient in industries like construction, longshoring, and shipping, where employees periodically rotate froin one firm to another. Finally, any struggling, risk-averse proprietor must surely take solace im knowing that workers' wages and conditions constitute at least one area immune from competition by a rival down the street.

\section{CONCLUSION}

I have this innage of Justice White. He has been burning the midnight oil and looks haggard and disheveled. The deadline for his first draft im Bonanno is two weeks past, he is still wrestling with the idea of "industrial peace," and he hasn't even touched the dozen other cases to which he has been assigned to write the opmions. He turns to Leshe.

"Professor," he says, "I need help. You have been sitting. here in this tranquil university town, thinking for months about an einployer's right to withdraw from inultieinployer bargaining. You know more about the subject than anyone else in the country. What should I do?"

"Well, Mr. Justice," rephes Leshe (they still say "Mr." at Mr. Jefferson's University), "economic analysis of multieinployer bargaining is 'devilishly difficult.' Even if we were certain about the welfare effects, 'the choice of a standard would not necessarily be dictated.' But at least the 'appropriate questions' are clear to me."

An angnished look crosses White's face. He stumbles off, muttering under his breath, "I guess 'industrial peace' will have to do ....."

Come on now, Leshe! You have almost written yourself a httle masterpiece. Push yourself to a conclusion. 